DOI https://doi.org/10.18551/rjoas.2017-04.19

\title{
THE EFFECT OF LEADERSHIP STYLE AND ORGANIZATIONAL CULTURE ON LECTURER'S JOB SATISFACTION
}

\author{
Suradi \\ Center for Education, Training and Development of Human Resources, \\ Financial Education and Training Agency, Ministry of Finance, Indonesia \\ E-mail: adidrs@yahoo.co.id
}

\begin{abstract}
This research aims to examine and analyze the effect of leadership style and Organizational Culture on Lecturer's job satisfaction. The research object is lecturer in Financial Education and Training Agency, Ministry of Finance. The method of this research is explanatory research which aims to know the variable effect of leadership style $\left(X_{1}\right)$, organizational culture $\left(\mathrm{X}_{2}\right)$ and job satisfaction $(\mathrm{Y})$. This research is done towards respondents. Besides, sampling technique used in this research is saturated sample. On the other hand, statistic analysis used is multiple regression analysis with helping tool like IBM SPSS Software version 23. The result of this research shows that leadership style and Organizational Culture, either holistically or partially, have effects on Lecturer's job satisfaction. From the discussion, it can be known that there are two leadership styles which can give effect significantly on Lecturer in Financial Education and Training Agency: Directive and Achievement Oriented leadership style. After doing regression by considering dummy gender variable and work location with robust standard error, it is confirmed that there is only one significant variable found: result-oriented leadership style. Result-oriented leadership style is the most appropriate style with the work patterns of Lecturer. As suggestion, Financial Education and Training Agency should make an innovation related to leadership style as the values of Ministry of Finance which are regarding to "Organizational Culture". Besides, Financial Education and Training Agency still needs to make a further approach through result-oriented leadership style.
\end{abstract}

\section{KEY WORDS}

Leadership style, organizational culture, job satisfaction, lecturers.

Ministry of Finance is placed in the strategic position in the governance of the Republic of Indonesia. Almost all economics aspects of country gives direct effects with the policy made by Ministry of Finance. The very strategic roles of Ministry of Finance are: (1) as state financial manager, (2) as fiscal policy holder, (3) as budget user, (4) as State General Secretary, and (5) as goods manager.

As the state financial manager, Ministry of Finance is responsible for achieving the target of state income. State Income is the right of Central Government acknowledged as net worth enhancer consisting of Tax Revenue, Non-tax revenue, and Grant Revenue. From 2010 to 2015, the amount of state revenue target increases to Rp.798,3 trilyun. To implement it, the development of Human Resources, especially through education and training, becomes something urgent and crucial.

Eskildsen et. al. (2004) states private and public Organization obtain maximum result through different ways. Privat coporate focuses more on dimensional system aspect, while public Organization focuses more on people aspect. Therefore, human resources management is the significant factor in public organization.

Based on review from some researches, it shows that human resources management in public Organization is extremely significant and urgent especially in Ministry of Finance because performance target that should be achieved in form of state revenue. It is due to the fact that state revenue will be used to pay operational activities of the country.

Financial Education and Training Agency has a duty to conduct education, training, and competency certification in field of state finance based on constitution regulation. To 
implement it, Financial Education and Training Agency has vision and mission: Becoming the Foremost Training and Education Institution in Obtaining Discipline, Professional, Highintegrity, and Responsible Human Resources on Finance and Country's Wealth. In doing that, Financial Education and Training Agency has expertise functional position called Widyaiswara. Widyaiswara position is the main role in running the duty of Financial Education and Training Agency for training and certification in state finance.

Structurally, Widyaiswara is controlled by structural advisor even if sometimes their level is under Widyaiswara. The success of a Widyaiswara is influenced by job satisfation perceived on their profession. There are several factors which can influence the job satisfaction of Widyaiswara, one of them are leadership style and Organizational Culture. Schein (1990) states: the very important responsibility of leadership is creating a very appropriate culture with the Organization. Based on researches' proof, it shows that there is a very close relatioship between leadership style adopted by top management and Organizational Culture.

Leadership style is the behavior form practiced by someone when using authority to influence the followers' perceptions about performance goal, self-development goal, organization and individual goal integrating and showing ways to achieve the goals by paying attention individual's characteristics. Meanwhile, organizational culture is a system done as habit of organization that makes them different from the other organization. Work satisfaction is a happiness gained from work because of various things achieved in work, such as reward, bonus, wok facility, or positional improvement. Work satisfaction makes somebody more motivated in work, therefore affect his productivity. This research aims to know the effect of leadership style and Organizational Culture on Widyaiswara's job satisfaction.

\section{THEORETICAL FRAMEWORK}

Leadership Style. The topic discussing about leadership and Organizational Culture has attracted scholars and practitioners to make a research. Ogbonna and Harris (2000) research about the empirical relationship proof between Organizational Culture, leadership style, and Organization performance. One of the conclusions of the research is leadership style is a strong predictor on Organizational Culture. Naderi and Jadidi (2014) conclude that: the correlation magnitude between leadership style and Organizational Culture is 0,81 . This reveals that leadership style choice appropriate for an organization or an institution plays an important role in creating the most appropriate Organizational Culture with the Organization.

This leadership style is enhanced by Robert J. House and Terence R. Mitchell in pada 1975. This theory is called Path-Goal Theory of Leadership because it mostly discusses about how a leader influences his employee's perception regarding to goal of work, private goal, and direction in achieving the goal. A leader becomes effective because the positive influence owned by the leader to motivate, conduct, and satisfies employees.

These are four leadership styles from Path-Goal Theory of Leadership: 1) Supportive leadership is a leadership which pays attention on employees' needs and creates comfortable circumstance in workplace, 2) Directive leadership is a leadership which enables employees to know what they are expecting to be done, 3) Participative leadership is a leadership which gives consultation to employees and considers their opinions and suggestions, 4) Achievement-oriented leadership is a leadership which sets challenging targets to achieve high performance standard.

Organizational Culture. According to Lunenbur (2011), an organization is considered very important to have Organizational Culture which can support performance of employees and organization because it can give significant effects on attitude and behavior of organization members. Organizational Culture can be a competitive and a main instrument if it can support strategy of an organization and can answer as well as solve environment challenge appropriately and quickly (Soedjono, 2005).

As stated by Bhatti and Qureshi (2007), effective organization should have culture which can enhance its employees' satisfaction. A research done by Satyawati and Suartana (2014) also shows that there is a positive effect between Organizational Culture and job 
satisfaction. Robbins (2015) defines organizational culture as a value and belief system owned by organization members to distinguish one organization to other organizations.

Denison (1990) defines organizational culture as values, beliefs, and basic principles which are the foundations of system and management practices as well as behaviors which improve and strengthen those basic principles. Indicators of organizational culture according to Denison and Mishra (1995) are involvement, consistency, adaptability, and mission.

Job Satisfaction. According to Robbins (2012), job satisfaction is positive feeling on someone's performance which is from the evaluation result on his characteristics. Job satisfaction portrays attitude more than behavior. A belief that employees who feel satisfied is more productive than those who do not feel satisfied. An individual who has high job satisfaction will show positive attitude toward his performance, while an individual who does not feel satisfied will show negative attitude toward his performance (Robbins, 2003). There are eight dimensions influencing performance satisfactions: (1) the work itsel, (2) Pay, (3) Promotion opportunity, (4) Recognition, (5) Work Condition, (6) supervision, (7) co-workers, and (8) company and management.

Widyaiswara. According to Minister of Administrative Reform and Bureaucratic Reform Regulation number 22 year 2014 Article 1, Widyaiswara is a civil cervant declared to have functional position with duty, responsibility, authority, and right to conduct Education and Training (teaching-learning process in Financial Education and Tranining Agency either classically or unclasically). Functional Position of Widyaiswara is a position covering scope, duty, authority, and right to educate, teach, and train the Civil Servants which is then called Dikjartih PNS; Evaluation and Training and Education Development which is then called Diklat. The stages of Widyaiswara's position are four: 1) Widyaiswara Beginner, 2). Widyaiswara Early, 3).Widyaiswara Junior, and 4).Widyaiswara Senior.

\section{METHODS OF RESEARCH}

This research is conducted to know the effect of leadership style variable $\left(X_{1}\right)$ organizational culture $\left(\mathrm{X}_{2}\right)$ and job satisfaction $(\mathrm{Y})$, thus this research is categorized as explanatory research.

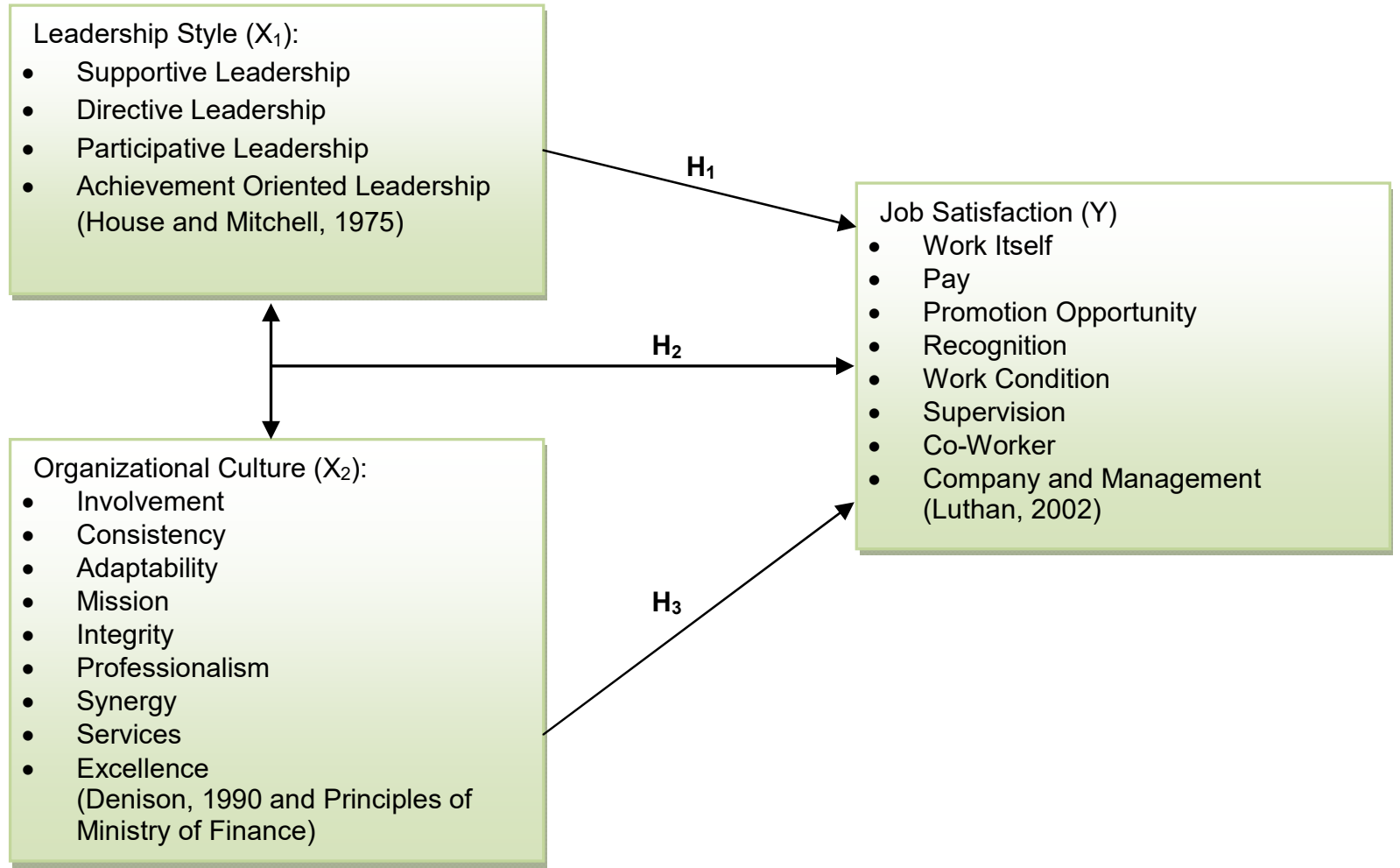

Figure 1 - Conceptual Framework 
This research is done in 158 lecturers of Financial Education and Training Agency who are in training center, finance training division, and Leadership Training Division in Magelang. Population of this research is 158 lecturers of Financial Education and Training Agency who are in research location.

\section{RESULTS AND DISCUSSION}

Validity and Reliability Test. In validity test, decision making is based on $r$ value (Corrected Total Correlation) $>r$ table in amount of 0,239, for $\mathrm{df}=30-2=28 ; \alpha=0,05$, so the statement is valid and vice versa. All counting result is more than $r$ Table which is 0,239 , so all statement in measuring tool is valid and can be continued to reliability test. Alpha formula is used in Reliability Test. Cronbach Alpha value is less than 0,60 , then its reliability level is not quite good; from 0,7 to 0,8 , its reliability level is acceptablel and above 0.8 is good (Ghozali, 2009), because all dimensions in measuring tool has reliability value more than 0,8 , so that measuring tool used in this research is valid and it can be continued to analysis data.

Classical Assumption Test. Normality Test, research data are normal, it is known from Asymp. Sig. (2-tailed) >0,503.

1. Linearity Test. From analysis result of linearity test, it is found that a relationship between leadership style variable and Organizational Culture toward Perfomance Satisfaction shows that Significance degree is $<0,05$, meaning that the variable of leadership style and Organizational Culture toward Performance Satisfaction has linear equation.

2. Autocorrelation test. Autocorrelation test calculation is obtained from statistics of Durbin Watson in amount of 1,570 . This means the value of Durbin Watson statistics is in between 1,55-2,46. Based on the condition, it is concluded that independent variables in this research is freed from autocorrelation.

3. Heteroskidastity Test. Both variables have insignificant regression coefficient value (Sig. > 0,05). Thus, heteroskidastity effect is not there or regression equation fulfills homokedestity assumption.

4. Multicolinearity Test. No independent variable having tolerance value less than 0,10 which means that there is no correlation among independent variables. The calculation result of Variance Inflation Factor (VIF) also shows the same in which there is no independent variable having VIF value more than 10 . So, it can be concluded that there is no multicolinearity among independent variables in regression model.

Determination Coefficient Test Result (R2). Determination Coefficient (R2) generally measures how far the model ability in explaining independent variables. Determination Coefficient value is between zero to one. Determination value is determined by Adjusted $R$ Square value. Determination R2 test result can be shown in Table 1.

Table 1 - Determination Coefficient Test Result (R2) Model Summary ${ }^{b}$

\begin{tabular}{|c|c|c|c|c|}
\hline Model & $\mathrm{R}$ & R Square & Adjusted R Square & Std. Error of the Estimate \\
\hline 1 & $0,729^{\mathrm{a}}$ & 0,531 & 0,521 & 30,71255 \\
\hline
\end{tabular}

a. Predictors: (Constant), Organizational Culture, Leadership Style;

b. Dependent Variable: Job Satisfaction.

Based on Table 3, it can be seen that Adjusted $R$ Square value is 0,521 meaning that dependent variable, job Satisfaction, can be explained by independent variables which are leadership style and organizational culture. While, the rest $47,90 \%$ is explained by other variables which are not inserted to this research model, for instance Motivation and Organizational Commitment.

Model Accuracy Test Result (F Test). F Statistics Test is to show whether the independent variable in the model has collective influence toward its dependent variable. $F$ Statistics Test result can be shown in Table 2. 
Table 2 - F Test ANOVA ${ }^{a}$

\begin{tabular}{|c|c|c|c|c|c|c|}
\hline \multicolumn{2}{|c|}{ Model } & Sum of Squares & df & Mean Square & F & Sig. \\
\hline \multirow{4}{*}{1} & Regression & 94094,834 & 2 & 47047,417 & 49,877 &, $000^{b}$ \\
\cline { 2 - 7 } & Residual & 83006,924 & 88 & 943,261 & - & - \\
\cline { 2 - 8 } & Total & 177101,758 & 90 & - & - & - \\
\hline
\end{tabular}

a. Dependent Variable: job Satisfaction

b. Predictors: (Constant), Organizational Culture, Leadership Style

Table 2 reveals that $F$ value is 49,877 with probability 0,000 . This means that probability value is $<0,05$, while the result obtained from $F$ table is 3,10 which means $F$ value $>\mathrm{F}$ tabel $(49,877>3,10)$, so that regression model can be used to predict job satisfaction or it can be concluded that leadership style and organizational culture collectively influences job satisfaction or the model is valid.

Hypothesis Test Result (t Statistics Test). T Statistics Test principally shows how for the influence of independent variable individually in explaining dependent variables. In t test, t counted value will be compared to t table value.

This is t statistics test result shown in Table 3.

Table 3 - $\mathrm{t}$ Test (Partial) Coefficients

\begin{tabular}{|c|c|c|c|c|c|c|}
\hline \multirow{2}{*}{\multicolumn{2}{|c|}{ Model }} & \multicolumn{2}{|c|}{ Unstandardized Coefficients } & \multirow{2}{*}{$\begin{array}{c}\text { Standardized Coefficients } \\
\text { Beta }\end{array}$} & \multirow{2}{*}{$\mathrm{t}$} & \multirow{2}{*}{ Sig. } \\
\hline & & B & Std. Error & & & \\
\hline \multirow{3}{*}{1} & (Constant) & 74,387 & 33,188 & & 2,241 & ,028 \\
\hline & Leadership Style &, 278 &, 084 & ,303 & 3,296 & 001 \\
\hline & Organizational Culture & .544 & 099 & .504 & 5,475 & 000 \\
\hline
\end{tabular}

a. Dependent Variable: job Satisfaction

The regression equation is shown in eq. (1).

$$
Y=74,387+0,278 X_{1}+0,544 X_{2}
$$

From eq. (1), it can be interpreted that:

- Job Satisfaction (Y). Bound variable value will be predicted by free variable. The bound variable of this research is performance satisfaction in which its value will be predicted by variables of X1 (leadership style) and X2 (organizational culture).

- Leadership style (X1) toward job satisfaction (Y). The value of this regression coefficient shows that contribution is given if variable of $X 1$ (leadership style) is positive meaning that every increasing variable of $\mathrm{X} 1$ (leadership style) in a unit will increase job satisfaction level $(Y)$ in the amount of 0,278 with condition that other variables are constant.

- Organizational culture $(\mathrm{X} 2)$ toward job satisfaction $(\mathrm{Y})$. The value of this regression coefficient shows that contribution is given if variable of $\mathrm{X} 2$ (organizational culture) is positive meaning that every increasing variable of $X 2$ (organizational culture) in a unit will increase job satisfaction level $(Y)$ in the amount of 0,544 with condition that other variables are constant.

Based on Table 3, it is found that $t$ counted value of is bigger than $t$ table value which is $3,296>1,987$ and significance value is $0,001<0,050$, so that leadership style gives positive influence and significance toward job satisfaction. Organizational culture counted balue is bigger than $t$ table value which is $5,475>1,987$ and significance value is $0,000<0,050$. Thus, organizational culture has positive influence and significance toward job satisfaction.

From statistics test above, it can be concluded that leadership style gives positive influence and significance toward performance satisfaction in Finance Education and Training Agency. This means that leadership style gives positive influence and significance toward job satisfaction. The better the ladership style, the better the job satisfaction and vice versa. 
On the other hand, organizational culture has positive influence toward performance satisfaction in Finance Education and Training agency. This means that if organizational culture is better then condition will be more conducive, so that it can give better contribution to improve job satisfaction.

\section{CONCLUSION AND SUGGESTIONS}

The research result shows that leadership style and organizational culture either holistically or partially influence Widyaiswara (Lecturer) Job Satisfaction in Financial Education and Training Agency. From discussion, it is known that there are two leadership styles which significantly influence job satisfaction of Widyaiswara (Lecturer) in Financial Education and Training Agency: Directive and Achievement Oriented leadership style. After doing regression by considering dummy gender variable and work location with robust standard error, it is confirmed that there is only one significant variable which is Achievement Oriented leadership style. Achievement Oriented leadership Style is the most appropriate model for Widyaiswara (Lecturer) performance pattern.

Financial Education and Training Agency is organizational unit which has main duty and function such as conducting education and training in state finance aspect. Financial Education and Training Agency is analogized as a chef that should serve food in line with era development. To achive it, Good Human Resources should be prepared. One of the important elements in Education and Training is Widyaiswara (Lecturer). By paying attention on one of the main managing elements, Widyaiswara, job satisfaction should be improved so that it is expected it can give positive influence toward Education and Training implementation and eventually it will improve their performance.

Based on the research result, Financial Education and Training Agency should make an innovation related to leadership style as the Values of Ministry of Finance which are regarding to "Organizational Culture". Besides, Financial Education and Training Agency still needs to make a further approach through result-oriented leadership style. The things that need to be improved are the advisor can give a challenge to the lecturers in order that they can make more achievements in terms of giving self-development chance based on their interests and skills, delegate a part of authorities appropriate with Widyaiswara (lecturers) and more flexible in accomplishing work. From organizational culture viewpoint, involvement and consistency hold main roles to elevate Widyaiswara (lecturers) job satisfaction. This positive thing especially supported by free culture, express opinion and self-development opportunity or better competence. These ideas are one of efforts that should be done by Financial Education and Training Agency to enhance its performance in the future.

\section{REFERENCES}

1. Bhatti, K. K. and Qureshi, T. M. 2007. Impact of Employee Participation on Job Satisfaction, Employee Commitment and Employee Productivity. International Review of Business Research Papers, 3(2): 54-68.

2. Denison, D. R. and Misra. 1995. "Toward Of Organizational Culture and Effectiveness". Organization Science, Vol.6, No.2, March-April.

3. Eskildsen, J. K., Kristensen, K and Hans, J. J. 2004. Private versus public sector excellence. The TQM Magazine 16, 1; ABI/INFORM Collection pg. 50.

4. Ghozali, I. 2009, Aplikasi Analisis Multivariate dengan Program SPSS, Cetakan ke IV, Semarang: Badan Penerbit UNDIP.

5. Lunenbur, F. C. 2011. Goal-Setting Theory of Motivation. International journal of management, business, and administration, 15(1).

6. Naderi, N and Jadidi, L. 2014. The Study of the effects between Leadership Style, Organization Culture, Employees Performance on Leadership Performance.International Journal of Academic Research in Business and Social Sciences, 4(12). p.196. 
7. Ogbonna, E. and Haris, L. C. 2000. Leadership style, organizational culture and performance: empirical evidence from UK companies. International of Human Resource Management, 11(4): 766-788.

8. Robbins, S.P. and Judge, T. 2015. Organizational Behavior. Boston: Pearson International Edition.

9. Satyawati, N. M. R. and Suartana, I. W. 2014. Pengaruh Gaya Kepemimpinan dan Budaya Organisasi terhadap Kepuasan Kerja yang Berdampak pada Kinerja Keuangan.E-Jurnal Akuntansi Universitas Udayana, 6(1): 17-32.

10. Schein, E.H. 1990. Organizational Culture and Leadership. San Francisco: John Wiley and Sons.

11. Soedjono. 2005. Pengaruh Budaya Organisasi terhadap Kinerja Organisasi dan Kepuasan Kerja Karyawan pada Terminal Penumpang Umum di Surabaya.Jurnal Manajemen dan Kewirausahaan, 7(1): 22-47. 